\title{
QUOTATIONS, TRANSLATIONS AND TRANSLITERATION
}

Unless otherwise stated, all quotations from the Qur'ān are taken from the English interpretation of Muhammad Marmaduke Pickthall. ${ }^{1}$ At times, I have compared his translation with that of other English interpreters of the Qur'ann, and these will be named in the text when they occur.

Unless otherwise stated, all translations of the Arabic texts are my own. All Arabic texts have been reproduced exactly from their sources, even when mistakes are extant in the said texts. The system of transliteration, given below, has been followed throughout the text, except in instances in which other authors have been quoted, in which case the said author's system of transliteration has been respected.

Except when quoting from other works, all dates are given according to the Islamic calendar (bigra), followed by a backslash and the Gregorian equivalent.

${ }^{1}$ PICKTHALL M.M., The Meaning of the Glorious Qur'ān, Dar al-Kitab Allubnani, Beirut and Dar al-Kitab al-Masri, Cairo (n.d.). 
viii

ANGELS HASTENING

SYSTEM OF TRANSLITERATION

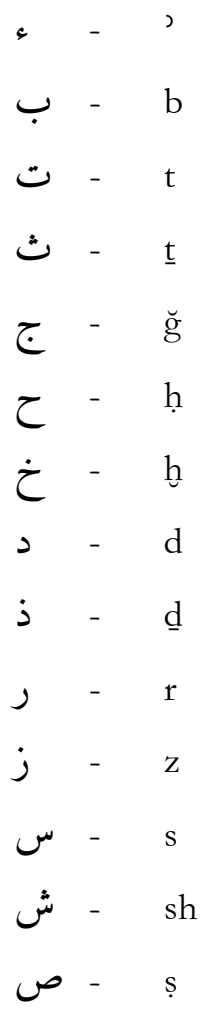

$$
\text { i } \quad-a, u
$$

T $-\bar{a}$

$9 \quad-\quad \bar{u}$
ض $\quad$ d

b - t

ظ $\quad$ - z

$\varepsilon-c$

$\dot{\dot{\varepsilon}}-\dot{g}$

ق - q

5) - $\mathrm{k}$

J -1

p - m

ن - n

- $\quad$ h

9 - w

ي - y

Short Vowels

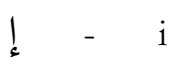

Long Vowels

ي - $\quad \overline{1}$ 


\section{LIST OF ABBREVIATIONS}

$\begin{array}{ll}\text { AD } & \text { Anno Domini } \\ \text { b. } & \text { bin (son) } \\ \text { bb. } & \text { bäb (chapter) } \\ \text { BC } & \text { before Christ } \\ \text { bk. } & \text { book } \\ \text { bt. } & \text { bint (daughter) } \\ \text { c. } & \text { circa } \\ \text { CE } & \text { common era } \\ \text { cf. } & \text { confer } \\ \text { ch. } & \text { chapter } \\ \text { Col. } & \text { The Letter to the Colossians } \\ \text { d. } & \text { died } \\ \text { Dan. } & \text { The Book of Daniel } \\ \text { Deut. } & \text { The Book of Deuteronomy } \\ \text { Eccles. } & \text { The Book of Ecclesiastes } \\ \text { ed. } & \text { editor } \\ \text { edn. } & \text { edition } \\ & \end{array}$




\begin{tabular}{|c|c|}
\hline edns. & editions \\
\hline eds. & editors \\
\hline eg. & for example \\
\hline et al. & and others \\
\hline etc. & etcetera \\
\hline Ez. & The Book of Ezekiel \\
\hline ff. & following \\
\hline GAL & Geschichte der arabischen Literatur \\
\hline GAS & Geschichte der arabischen Schrifttums \\
\hline Gen. & The Book of Genesis \\
\hline Heb. & The Letter to the Hebrews \\
\hline Ibid. & ibidem \\
\hline Is. & The Book of Isaiah \\
\hline Jdg. & The Book of Judges \\
\hline Jn. & The Gospel of St. John \\
\hline I Kgs. & The First Book of Kings \\
\hline lit. & literally \\
\hline Lk. & The Gospel of St. Luke \\
\hline Mt. & The Gospel of St. Matthew \\
\hline n. & number \\
\hline n.d. & no date \\
\hline Num. & The Book of Numbers \\
\hline nn. & numbers \\
\hline n.n. & no number \\
\hline n.p. & no publisher \\
\hline nt. & footnote \\
\hline pl. & plural \\
\hline Q. & Qur’ān \\
\hline Rev. & The Book of Revelation \\
\hline Rm. & The Letter to the Romans \\
\hline I Sam. & The First Book of Samuel \\
\hline
\end{tabular}

